\title{
ТАТЬЯНА ВОЛОКИТИНА
}

\section{Дата, изменившая историю страны (к 75-летию событий 9 сентября 1944 г. в Болгарии)}

Аннотачия. Статья посвящена знаковому в истории Болгарии событию, положившему начало переходному периоду народной демократии и формированию политического режима советского типа. Оценки того, что произошло 9 сентября 1944 г., менялись в зависимости от конъюнктуры. Вплоть до краха коммунистического режима в стране в ноябре 1989 г. они оставались в рамках господствовавшей тогда идеологической парадигмы. Наше время, открывая перед исследователями возможность объективного изучения прошлого, как оказалось, рождает соблазн нового мифотворчества.

Ключевые слова: 9 сентября 1944 г., восстание, переворот, револючия, политические и научные дискуссии, современная историографическая ситуация.

C обытийная канва вполне ясна. 9 сентября 1944 г.в Болгарии, участвовавшей в глобальном мировом противостоянии на стороне гитлеровской Германии, была реализована оппозиционная альтернатива монархическому режиму (по определению того времени - «монархо-фашизму»). Власть перешла к объединявшему левоориентированные политические силы Отечественному фронту (ОФ), участники которого выступали, хотя и с разной степенью активности, против прежнего режима и союза с фашистской Германией, за соблюдение конституционных норм, прав и свобод болгарских граждан. Коалиция включала представителей действовавших от имени рабочего класса Болгарской рабочей партии (БРП) 1 и Болгарской рабочей социал-демократической партии (БРСДП), левого крыла «Пладне» («Полдень») крестьянской партии Болгарский земледельческий народный союз (БЗНС) и политической группы «Звено» - военной, в основном офицерской, организации. Ведущая роль в ОФ принадлежала коммунистам - главным организаторам движения Сопротивления в годы войны.

Новым лидерам предстояло «предъявить» мировому сообществу смену власти, что было крайне важно в условиях продолжавшейся войны, а также подумать о судьбе Болгарии в дальнейшем, на этапе перехода к послевоенному мирному урегулированию.

1 Болгарская рабочая партия (БРП) впоследствии дважды меняла свое название: в конце сентября 1944 г. была переименована в Болгарскую рабочую партию (коммунистов) - БРП(к), а на V съезде в декабре 1948 г. - в БКП.

Сведения об авторе: ВОЛОКИТИНА ТАТЬЯНА ВИКТОРОВНА - ведущий научный сотрудник Института славяноведения РАН, зав. отделом Восточной Европы после Второй мировой войны, доктор исторчческих наук, tanyaslav@rambler.ru. 
При этом ключевое значение приобретали факторы (внешние и внутренние), которые способствовали установлению нового режима и, соответственно, его легитимности.

Первое, на что хотелось бы в связи с этим обратить внимание, - впечатления сторонних наблюдателей от увиденного в столице, центре политической жизни страны. Посол Италии в Софии Франческо Дж. Мамели вспоминал, что «государственный переворот...в ночь с 8 на 9 сентября 1944 г. ...был молниеносным и поначалу полностью бескровным...Утром, не считая нескольких танков и пулеметов перед зданием Военного министерства, София выглядела как обычно. Лишь к 13 часам появились первые красные патрули, и началась беспорядочная раздача оружия населению» [Цит. по: Баева, с. 109]. Наблюдение дипломата подтверждают и историки, отметившие, что поначалу народ спокойно, если не индифферентно, отнесся к смене власти [Например, см.: Валева, с. 297], и что бурная поддержка перемен последовала «вдогонку» за событиями. Уже 12 сентября оказавшиеся в Софии советские военные корреспонденты наблюдают эмоциональный подъем населения, напомнивший им октябрьские дни 1917 г. в России -толпы, митингующие на улицах и площадях, красные флаги с серпом и молотом на зданиях государственных учреждений, красные банты и красные звездочки на штатских и военных... Те же ощущения «недавно происшедшего революционного переворота», «горения... человеческой массы» [Информация военных... с. 111-112]. Первые официальные заявления констатируют: в стране победила «антифашистская революция». Об этом говорилось в циркуляре № 5 ЦК БРП от 12 сентября, разосланном парторганизациям на местах, и в радиограмме, которую13 сентября руководивший оперативной работой Политбюро ЦК БРП Трайчо Костов направил находившемуся в Москве Георгию Димитрову [Непубликувани радиограми... с. 29]. Однако Димитров 15 сентября в ответной радиограмме от имени Загранбюро ЦК отклонил подобную оценку как неправильную, указав, что в сложившейся обстановке решающее значение имеют «общенациональные, а не классовые цели» [Цит. по: Аврамов, с. 83]. С позиций сегодняшнего дня очевидно, что намерение отказаться от раздражающего многих термина «революция» было продиктовано желанием Москвы не обострять отношения с западными союзниками, избежать подозрений с их стороны в намерении «советизировать» Болгарию. Однако не следует исключать и того, что указанная оценка событий 9 сентября местными коммунистами вызывала у советского руководства сомнения и с точки зрения ее соответствия реальной обстановке.

Димитров и Загранбюро ЦК охарактеризовали события 9 сентября как «народное» (или «всенародное») вооруженное восстание. Его направленность против монархо-фашистской диктатуры и германских оккупантов подчеркивалась особо. В центральном органе компартии - газете «Работническо дело» от 20 сентября 1944 г. указывалось, что созданное в результате восстания правительство ОФ ни по составу, ни по методам управления не являлось «коммунистическо-советским». Более того, отмечала газета, такой характер правительства не соответствовал бы ни внутренним, ни международным условиям [Работническо дело. 20 септември 1944 г.].

Данная установка прижилась не сразу: партийное руководство, находившееся в стране, некоторое время пыталось сочетать общенациональные задачи смены влас- 
ти с первыми оценками сентябрьских событий как революции. Это подчеркивало масштаб акции, ее массовый характер и популярность, указывало на величие, необратимость, глубокие последствия и перспективы перемен. А кроме того объясняло разгул «революционной стихии», в частности, имевшие место в первые дни после 9 сентября расправы без суда и следствия', как проявление имманентно присущего любым революциям насилия. Пример такого сочетания - выступление Тр. Костова 25 сентября на Софийской областной партконференции. «Антифашистская революция 9 сентября победила как национально-освободительное движение на широкой национальной основе, - подчеркнул Костов. - Этот факт мы никогда не должны забывать, так как из его правильного понимания следует и правильное решение вопроса о том, какие задачи мы можем и должны поставить после победы» [Работническо дело. 27 септември 1944 г.].

При определении сущностных черт власти ОФ болгарские коммунисты исходили из разработанной VII конгрессом Коминтерна концепции единого и народного фронта и, особенно, политического опыта Гражданской войны 1931-1939 гг. в Испании. Вошедший тогда в лексикон коммунистов и социалистов (социал-демократов) термин «народная демократия» (чаще - «новая») фиксировал ее отличие как от «старой» западной демократии, так и от советской формы политической власти, в основе которой лежала диктатура пролетариата. Вскоре после образования в сентябре 1936 г. испанского правительства Народного фронта с участием коммунистов Г. Димитров на заседании Секретариата Исполкома Коминтерна подчеркнул, что демократическая республика, за которую ведет борьбу испанский народ, не будет ни старой демократической республикой, ни советским государством. Возникнет «особое государство с подлинной народной демократией», «государство антифашистское, левое, с участием подлинно левой части буржуазии», при «решающем влиянии» Народного фронта [Димитров Избранные...т. 2, с. 244-245]. Возможной формой будущего государства Димитров считал «парламентскую республику нового типа», ломающую рамки буржуазной демократии. Однако он не вышел за «красные флажки» основополагающего маркистско-ленинского постулата о диктатуре пролетариата и увязал «новое» государство с «особой формой демократической диктатуры рабочего класса и крестьянства» [Там же].

На исходе Второй мировой войны, в обстановке подъема «народного радикализма», настроения европейцев определяла тяга к демократизации. «То, что война велась не просто против Германии или Италии..., а против фашизма, - отмечал английский исследователь Р. Милибенд, - придало ей яркую идеологическую окраску - на первый план была выдвинута защита демократических ценностей и прославление простого человека. Вступление России в войну и ее упорное сопротивление усилило эту идеологическую окраску...» [Милибенд, с. 381-382]. Зримо проявились особое внимание и интерес к различным модификациям социалистической идеи, включая советскую модель, что обусловливалось победоносными военными усилиями СССР, подтвердившими жизненность и эффективность социалистического строя.

1 По некоторым данным, жертвами самосуда и «революционной ярости» стали более 18 тыс. чел. [Исусов За някои... с. 10]. 
В советской сфере влияния, куда по договоренности с союзниками по антигитлеровской коалиции была включена Восточная Европа, социалистическая перспектива осознавалась особенно четко. Народная демократия как переходный период увязывалась в массовом сознании с продвижением к социализму, но своим, «национальным» путем. Для болгарских коммунистов осмысление такого варианта развития не было простым и потребовало определенных усилий в процессе ревизии идейно-теоретических установок прошлого. «Перемена 9 сентября, - отмечалось в теоретическом партийном журнале «Съвременник», - не является обычной сменой одного буржуазнодемократического правительства другим..., а представляет собой качественно новое изменение, новую, более высокую ступень в развитии страны» [Съвременник, с. 51].

Бурное обсуждение вопроса, что представляла собой эта ступень, развернулось на VIII пленуме партии весной 1945 г. Хотя мнения делегатов разделились, стало ясно, что дорогу активно начинает пробивать трактовка народной демократии как «власти демократической части буржуазии в союзе с рабочими и крестьянами» [Костов, с. 599]. Об этом говорил и вернувшийся на родину Г. Димитров, выступая в декабре 1945 г. в Народном собрании [Димитров,Костов, Югов, с. 5]. Акцент на коалиционном и, следовательно, компромиссном характере власти ОФ выразился в весьма примечательном, с нашей точки зрения, решении пленума «одобрить участие партии в правительстве Отечественного фронта» [Българската... с. 4].

Временна́я протяженность существования коалиционной системы власти представлялась на том этапе весьма значительной (широкое хождение получило определение «эра ОФ»), а содержание «переходного периода» маркировали такие его признаки, как общественный консенсус, парламентская демократия и партийный плюрализм, несовместимые с гражданской войной и «властью советов». Опорой власти в переходный период объявлялись не только «трудящиеся» и значительная часть средней буржуазии, но и представители ее крупных («патриотических») кругов, что открывало возможность эффективного решения трудных задач восстановления экономики по примеру советского НЭПа. Таким представлялся «национальный» путь развития, предлагавшийся стране и составивший основу концепции народной демократии в ее первоначальном, либеральном, варианте.

Однако этот вариант оказался кратковременным вследствие резкого изменения международной обстановки: вслед за первыми «заморозками» в отношениях между партнерами по антигитлеровской коалиции последовало их ухудшение, вполне ясно определившее перспективу превращения послевоенного мира в биполярный. Осенью 1947 г. с созданием Коминформбюро был взят курс на интенсификацию революционного процесса в странах советской сферы влияния и развенчание концепции «национальных путей» к социализму. На учредительном совещании Коминформа в польском городке Шклярска-Поремба в докладе А.А. Жданова, по справедливому замечанию болгарского историка Д. Драганова, руководству компартий народно-демократических стран уже была предложена опиравшаяся на советский опыт «подробная и точная программа действий» [Драганов, с. 57]. В коммунистических партиях и их высших эшелонах «зеленый свет» зажегся перед носителями леворадикальных настроений, 
сторонниками «пришпоривания» общественно-политических процессов [Исусов Сталин и България, с. 144, 220], не исключавшего ориентацию на силовое решение политических задач.

Опираясь на установки Коминформа, в октябре 1947 г. XIII пленум ЦК БРП(к), проходивший в отсутствие Г. Димитрова и В. Коларова, подверг тенденциозной политической и теоретической переоценке прежний курс преобразований в стране. С основным докладом выступил секретарь ЦК Вылко Червенков. На основе его выводов политическую линию партии отныне предлагалось выстраивать, ориентируясь на переход к непосредственному построению социализма, развертывая решительное наступление на «реакционные и контрреволюционные силы», то есть обостряя классовую борьбу в стране. Новые установки, по существу, явились прелюдией к ревизии прежних оценок событий 9 сентября и перспектив власти Отечественного фронта.

Острая дискуссия развернулась в связи с этим при обсуждении проекта новой программы ОФ на XIV пленуме партии (январь 1948 г.). Большинство делегатов, оценивая события 9 сентября как революцию, тем не менее вкладывали в это определение разное содержание. Одни придавали ей социалистический характер (с самого начала, целиком и всесторонне), другие настаивали на ее народно-демократическом характере, отличном как от буржуазно-демократического, так и от «чистого» социалистического (то есть советского) вариантов. Третьи, исходя из приоритета общенациональных интересов, указывали, что задачи социалистической революции в момент смены власти вообще не стояли на повестке дня. Возражая протагонистам идеи «чистых революционных форм», Г. Димитров подчеркнул, что в сентябре 1944 г. с победой восстания страна пошла не по пути социализма, а по пути к социализму. И это, как отмечал видный историк академик М. Исусов, «была не игра слов, а существенное различие в концепциях» [Исусов Георги Димитров... с. 51]. Полагая, что значение событий 9 сентября ограничивалось созданием условий для будущего коренного государственного переустройства, Димитров критиковал Червенкова, утверждавшего, что якобы ошибочные оценки восстания затормозили дальнейшие мероприятия партии. «Если мы серьезно, как марксисты... исходим из реальной действительности, а не выдаем желаемое за действительное, то мы должны прийти к единственному [верному] заключению, что замедление не было ошибкой», - подчеркнул Димитров [Цит. по: Исусов Комунистическата... с. 275].

Дискуссии 1947-1948 гг. показали, что в руководстве БРП(к) и среди партийного актива продолжали соседствовать определения «революция» и «народное восстание» 9 сентября. Но если последнее отражало прежде всего конкретные события и характеризовало путь или методы взятия власти, то «революция», понятно, предполагала скачок в развитии страны, причем все громче звучали голоса, обосновывавшие ее социалистический характер. Объективная основа этого коренилась в динамике развития, в качественных изменениях народно-демократической системы власти к 1948 г. При этом оценки ее актуального состояния ретроспективно переносились на предыдущие годы, что само по себе было некорректным и недиалектичным, поскольку игнорировались особенности преобразовательного процесса и конкретных мероприятий народ- 
ной власти (поэтапная экспроприация капиталистической собственности, постепенное вытеснение отдельных групп буржуазии, относительно мирное общественно-политическое развитие на широкой социальной основе и пр.).

Наиболее отчетливо это проявилось на XVI пленуме ЦК БРП(к) в июле 1948 г. Он был созван после бухарестского совещания Коминформа, осудившего руководство КПЮ за «ошибки» и «отход» с позиций марксизма-ленинизма. Болгарские коммунисты, «извлекая урок» из югославского случая, были вынуждены сообразовываться с новыми международными условиями и более жесткими установками Москвы. Под давлением обстоятельств произошли изменения и в прежней позиции Г. Димитрова. Отступив от собственных формулировок января 1948 г., он в порядке «самокритики» поддержал выводы Червенкова, прозвучавшие на XIII пленуме ЦК БРП(к) в октябре 1947 г. Однако, судя по последующим высказываниям болгарского лидера, подобная переоценка ценностей была для него весьма непростой и не стала окончательной. Это выразилось в попытках найти «золотую середину», отстаивая народную демократию как сравнительно длительный переходный период.

С того времени в партийном лексиконе по отношению к 9 сентября уживались определения «революция» и «народное восстание». Последнее отражало прежде всего конкретные события и характеризовало способ взятия власти.

Состоявшийся в декабре 1948 г. V съезд БКП расставил все точки над і. Незадолго до партийного форума стала известна сталинская позиция, согласно которой переход от капитализма к социализму без диктатуры пролетариата невозможен. 6 декабря 1948 г. в беседе с болгарскими и польскими коммунистами в Москве советский лидер, рассматривая болгарский вариант взятия власти, подчеркнул, что он был реализован «не через внутреннее восстание, а с нашей, советской армии, помощью, то есть легко, без особых усилий». Это, по словам Сталина, открывало возможность «вернуться к той форме [диктатуры пролетариата], о которой говорили Маркс и Энгельс, т.е. к народнодемократической парламентской форме», обойтись без установления советского режима (организации «советов» как органов власти). «Для вас, - говорил Сталин, - народной демократии достаточно, чтобы перейти от капитализма к социализму. Но этот режим будет осуществлять диктатуру пролетариата» [Димитров Дневник... с. 644-645]. Понятно, что сталинская установка выходила за рамки болгарского «случая», приобретала универсальный характер и статус «последнего слова» высокой теории: функции диктатуры пролетариата были объявлены имманентно присущими народно-демократической власти. Для коммунистов стран «социалистического лагеря» это стало императивом.

В политическом отчете на съезде Димитров напомнил, хотя и крайне осторожно, о концепции «болгарского пути» через народную демократию, увязав ее с функционированием коалиционной системы ОФ. Примечательно, что эту концепцию он противопоставил проявлениям в БКП «левизны», «революционной» демагогической фразеологии, которая только затрудняла, по его словам, переход к социализму. Димитров имел в виду призывы болгарских «левых» «открыто говорить о социализме», включить 
в программные документы ОФ «ясные указания о социалистическом пути развития Болгарии» [АВП РФ. Ф. 074. Оп. 36. П. 134. Д. 8. Л. 40], иными словами, сократить переходный период в стране. Понятно, что социалистический путь в интерпретации «левых» мог означать только одно - ускоренное внедрение советской модели.

Сказанное Димитровым не следует трактовать как проявление какой-либо его оппозиционности установкам Москвы. Речь шла, на наш взгляд, лишь о желании несколько «растянуть» этап народной демократии, сделать переходный период более естественным, плавным, менее болезненным, как любил говорить болгарский руководитель. Димитрову хотелось минимизировать издержки внедрения советской модели, с которой он был знаком не понаслышке и неизбежность которой для Болгарии ясно осознавал. С позиций сегодняшнего дня расчеты Димитрова видятся наивными и нежизнеспособными: как и другие страны «социалистического лагеря», Болгария была обречена на копирование «матрицы».

V съезд в конечном счете принял «правильные» решения. Отступил и Димитров. Под прямым нажимом руководителя советской делегации, секретаря ЦК ВКП(б) М.А. Суслова [Исусов Политическият живот... с. 392] в заключительное слово на съезде болгарский лидер включил формулировку о «двух формах диктатуры пролетариата» - советской власти и народной демократии. Размышления Димитрова о народной демократии как коалиционной переходной форме до основной массы коммунистов не дошли: при подготовке доклада к публикации «крамольные» места были вычеркнуты [РГАСПИ. Ф. 575. Оп. 1. Д. 58. Л. 86].

Материалы, поступавшие в ЦК партии с мест, в том числе в ходе предсъездовских конференций в конце ноября - середине декабря 1948 г., свидетельствовали о трудностях восприятия оценок характера власти в стране партийной массой. Обобщенные информационные записки, составлявшиеся в организационно-инструкторском отделе ЦК БРП(к), фиксировали, что «повсюду» задавались вопросы: «Есть ли различия между диктатурой пролетариата в СССР и у нас?», «Когда установлена в Болгарии диктатура пролетариата?», «Какова разница между советской и народно-демократической властью?», «В чем отличие нашего переходного периода от НЭПа?», «Каковы характерные черты кулака?» [ЦДА. Ф. 1 Б.Оп. 12. А.е. 496. Л. 27] и пр. Вряд ли решения V съезда сняли эти вопросы, тем более что оценки народной демократии продолжали испытывать на себе влияние политической и идеологической конъюнктуры, причем по-прежнему главным источником новых веяний являлась советская сторона.

В июне 1949 г. известный философ, дипломат и общественный деятель П.Ф. Юдин, опираясь на пример стран «социалистического лагеря», сформулировал на страницах «Правды», что «народно-демократическая революция была формой социалистической революции, исполнив те же исторические задачи, что и социалистическая революция в СССР» [Юдин].

Появление в советском партийном официозе такого материала, естественно, не могло произойти без санкции «верхов» (самостоятельность или недосмотр в подобного 
рода делах исключались!) и потребовало от национальных коммунистов реакции. Болгары решили действовать испытанным методом - обратиться за советом в Москву. Случай вскоре представился: в конце июля 1949 г., уже после кончины Г. Димитрова, делегация в составе В. Червенкова, А. Югова и Г. Дамянова встретилась со Сталиным для обсуждения широкого круга внутриполитических вопросов. Ночью 30 июля на даче Сталина состоялись консультации, в ходе которых речь зашла о режиме народной демократии, перспективах Отечественного фронта и народных советов. В итоге стороны согласились, что период с 9 сентября 1944 г. до принятия в конце декабря 1947 г. закона о национализации промышленности и банков явился «подготовительным», когда укреплялись элементы народной демократии. С национализации берет начало «своеобразно оформленная диктатура пролетариата». «Диктатура пролетариата не может возникнуть до национализации крупного капитала», - подчеркнул Сталин. Болгары с вниманием выслушали рассуждения советского руководителя о возможности прийти к социализму «без советской власти», о том, что для мелкой буржуазии народная демократия - более приемлемая и более легко воспринимаемая форма, нежели пролетарская диктатура, и, коль скоро международная обстановка позволяет, от народной демократии «не следует отказываться». На вопрос Червенкова, «разовьется ли народная демократия в Болгарии в советскую власть», Сталин не дал однозначного ответа: «Куда придем? - не знаю. Может быть, к советской власти. Не уверен. Дело не в названии, а в классовой сущности. А она одна - и у вас, и у нас. Ваши народные советы - зародыш советской власти. Они, в зависимости от ликвидации капиталистических элементов, все больше будут развиваться в советы депутатов трудящихся, как у нас. [...] Когда разовьются народные советы, отпадет Отечественный фронт как орган мобилизации масс. Может быть, ОФ останется как форма агитационно-пропагандистского отдела» [ЦДА. Ф. 1 Б. Оп. 5. А.е. 42. Л. 48-49]. Показательно, что по ходу беседы Сталин неоднократно обращался к обстановке в Китае, сравнивал ситуацию в азиатской стране и странах Восточной Европы, что было вполне понятно: в первой половине 1949 г. в Москве внимательно изучали вопросы будущего государственного устройства Китая, готовились к их обсуждению с китайскими товарищами. Революционную власть в стране Сталин характеризовал как демократическую диктатуру рабочих и крестьян, отмечал необходимость «сравнительно продолжительного сотрудничества» с китайской буржуазией и, учитывая ее антиамериканские настроения, отказа от развертывания борьбы между трудом и капиталом [Галенович]. Китайский режим, резюмировал Сталин, еще не режим народной демократии, а последний суть «своеобразная форма диктатуры пролетариата» [ЦДА. Ф. 1 Б. Оп. 5. А.е. 42. Л. 47-48].

Установки, привезенные из Москвы, легли в основу доклада В. Червенкова на торжественном заседании в связи с 5-летием народной власти в сентябре 1949 г. «Восстание 9 сентября, - отметил Червенков, - положило начало таким глубоким политическим, социальным, экономическим и культурным преобразованиям, которые подготовили условия (курсив мой. - T.B.), чтобы у нас создалась и укрепилась подлинная народная демократия - своеобразная форма диктатуры пролетариата. Национализация капиталистических предприятий и банков [1947 г.]... была решающим шагом в этом отношении» [Червенков, с. 205]. Иными словами, утверждение пролетарской диктатуры рассматривалось как процесс, который постепенно приобрел законченность в виде 
оформившегося «подлинного», то есть не нагруженного ненужными либеральными чертами народно-демократического режима, приближавшегося к советскому типу. Хронологические рамки этого процесса - 1944-1948 гг. - Червенков уточнил, выступая в декабре 1949 г. на митинге в Софии в связи с предстоящими выборами в народные советы. Он подчеркнул, что проведенные в стране в эти годы преобразования «по существу сыграли такую же историческую роль, что и Великая Октябрьская социалистическая революция в России», хотя и осуществились другим, нежели в СССР, путем [Работническо дело. 17 декември 1949г.].

Судя по конкретным материалам, неоднократные уточнения оценок и характеристик усваивались рядовыми коммунистами с трудом, перестановка акцентов с использованием казенного партийного «новояза» рождала путаницу в головах: летом 1950 г. «Paботническо дело» было вынуждено констатировать, что вопрос о характере восстания 9 сентября 1944 г. и установленной в его результате власти постоянно поднимался на собраниях партактива и обсуждался в кругах партийной интеллигенции [Работническо дело. 29 юни 1950 г.].

Видимо, это обстоятельство стало одной из причин того, что в 1950 г. Болгарская академия наук объявила открытую дискуссию по вопросу о характере восстания 9 сентября и болгарского народно-демократического государства. Если до того времени осмысление указанной проблемы, а по существу - самоидентификация режима, являлось прерогативой партийных функционеров, то теперь дело было за наукой.

Однако творческой дискуссии не получилось. Участвовавшие в обсуждении философы, экономисты, юристы в своих выводах не выходили за рамки партийных установок - прежних и новых [Подробнее см.: Волокитина, с. 15], а после заключительного «слова», а точнее, двухчасовой речи Червенкова был подведен окончательный итог. Как позднее вспоминал видный экономист К. Добрев, с того времени, отбросив прежнюю идею о «подготовительном» периоде, «начали [единодушно] писать..., что диктатура пролетариата ведет свое начало с 9 сентября». Кроме того, впервые иным точкам зрения была дана политическая оценка как «меньшевистским» и «троцкистским» [Там же]. Круг замкнулся: партийная формула была перенесена в общественную мысль, претендующую на научность [Даскалов, с. 313].

Прошло немного времени, и советские философы вновь стали возмутителями спокойствия: оформилась концепция двух этапов народной демократии, генетически восходившая к «теории двух стадий». В основе последней лежало утверждение, что развивающиеся страны должны пройти этап буржуазно-демократической революции, а затем начать движение к социалистической демократии. Сначала в лекции перед партактивом Московской городской и областной организаций ВКП(б), а затем на страницах журнала «Большевик» известный философ А.И. Соболев, ссылаясь на опыт европейских стран народной демократии, подробно обосновал идею перерастания буржуазно-демократической революции нового типа (I этап) в социалистическую (II этап). Народная демократия, отнесенная автором к новому типу буржуазно-демократических революций, по классовому содержанию определялась им как «нечто вроде демокра- 
тической диктатуры пролетариата и крестьянства при руководящей роли рабочего класса». При этом особенно подчеркивалась ее направленность против империализма и фашизма. Вместе с тем на первом этапе, отмечал ученый, решались отдельные задачи буржуазно-демократического характера - например, проведение аграрных реформ. В последующем гегемония рабочего класса во главе с компартиями обеспечила переход народно-демократических стран на путь социалистического развития [Соболев, с. 28-29].

Понятно, что новое слово, прозвучавшее из Москвы, не прошло незамеченным. Болгарская сторона поспешила уточнить, отражает ли публикация в «Большевике» официальную позицию ЦК ВКП(б). Весной 1952 г. на эту тему болгары беседовали с В.М. Молотовым, Г.М. Маленковым и А.И. Микояном. Ответ был однозначным: советским партийным руководством указанные оценки не рассматривались и не одобрялись [АВП РФ. Ф. 074. Оп. 45. П. 203. Д. 15. Л. 12]. В какой-то мере это развязывало болгарам руки.

В силу блоковой дисциплины теория двух этапов сразу же была принята на вооружение национальными коммунистами [Szymczak, s. 17] В Болгарии ее первым толкователем вновь стал Червенков. Но в мае 1952 г. на III съезде ОФ он предложил собственную интерпретацию соболевской концепции. В отличие от советского ученого, подчеркивавшего качественное изменение власти - от буржуазно-демократической к социалистической, - Червенков очертил этапы развития одной и той же по характеру власти (диктатуры пролетариата в форме народной демократии), отличавшиеся единственно степенью «зрелости» диктатуры. Границей между этапами явилось знаковое, как и прежде, событие - национализация промышленных предприятий и банков в декабре 1947 г. Содержание второго этапа болгарский руководитель связал с процессом построения основ социализма [Третиконгрес... с. 33].

Авторы научных и научно-пропагандистских сочинений тех лет следовали концепции двух этапов, подчас искусственно конструируя схемы преемственности и логической связи фактов. Так, из утверждения, что накануне 9 сентября 1944 г. страна стояла перед социалистической революцией (притом что сохранялся значительный объем нерешенных буржуазно-демократических задач), некоторые авторы делали вывод, что борьба трудящихся против фашизма, за демократические права была чисто тактической задачей. Акад. Павлов, например, утверждал, что задачи буржуазнодемократического характера решались исходя из тактических соображений, «лишь попутно» [Павлов За марксическа... с. 397], хотя прежде он констатировал «преимущественное» решение именно этих задач на первом этапе революции. Интересами тактики объяснялись также лозунг создания правительства Отечественного фронта и сохранение до осени 1946 г. монархического института и регентства [См., например: Чаръкчиев За характера на народнодемократическата... ЧаръкчиевЗа характера на нашата... Гиндев За някои... Павлов Вълко Червенков.... Х. Характерно, что при некоторой нюансировке такой ход рассуждений бытовал и значительно позднее, в 19701980-е гг. [См., например: Гиндев Общото... История на антифашистката... Горненски и др.] 
Вместе с тем болгарское руководство испытывало определенные трудности. Следовало как-то определиться с прежними установками Сталина по вопросу о характере народной власти в Болгарии, в которых отсутствовало положение о перерастании революции. Ситуацию осложнило издание в 1954 г. под грифом Института экономики АН СССР учебника «Политическая экономия», закрепившего выводы о двух этапах и перерастании буржуазно-демократической революции в социалистическую. Проигнорировать появление учебника не представлялось возможным, поскольку он являлся не только итогом экономической дискуссии 1951 г. в Советском Союзе [Подробнее см.: Мрачковская], но и учитывал динамику позиции Сталина: изданная в конце 1952 г. его работа «Экономические проблемы социализма в СССР» была написана на основе замечаний по проекту учебника.

Выходом из сложной ситуации Червенков посчитал обращение к Н.С. Хрущеву. 18 февраля 1955 г. в письме советскому руководителю [АВП РФ. Ф. 074. ОП. 45. П. 203. Д. 15. Л.8-13] он «по поручению ЦК КП Болгарии» выразил несогласие с применением теории перерастания революции к болгарским реалиям и изложил собственное видение двух этапов развития революции в стране в духе своего выступления на III съезде ОФ. Напомнил он и о встрече со Сталиным в 1949 г. Выражением изменений, ощущавшихся к тому времени в отношениях внутри «социалистического лагеря», явилась прямая критика советских установок, содержавшихся в учебнике по политэкономии, как «слишком схематичных», лишенных конкретного анализа особенностей развития революции в каждой стране и сводивших все страны «к общему знаменателю». «Но ведь есть же разница в историческом развитии между Китаем и Болгарией, между Болгарией и Румынией и т.д., - задавал Червенков риторический вопрос. - Неизвестно, например, почему Китай может вступить в период социалистического переустройства страны с момента образования народной власти..., а Болгария не может, в ней непременно должно происходить перерастание одной революции в другую, хотя никакого помещичьего землевладения в стране не было». Не обошел болгарский руководитель и вопрос о давлении, которое оказывали советские преподаватели на болгарских учащихся в вузах: «В некоторых высших учебных заведениях в Советском Союзе, где учатся и болгарские товарищи, отдельные профессора настаивали на обязательном восприятии данной учебником по политической экономии оценки характера революции в народно-демократических странах и даже некоторое время отказывались принимать диссертационные работы, если в них не была отражена именно эта оценка». Обращаясь к ЦК КПСС за советом, «как поступить в данном случае», Червенков рассчитывал «устранить неудобное положение» [Там же. Л.13].

Был ли получен ответ на обращение Червенкова? Думается, Хрущеву было не до того: начиналась подготовка к XX съезду КПСС. А на нем, как известно, наметились новые подходы к проблеме многообразия путей к социализму с акцентом на мирном переходе к новой общественно-политической формации.

Копируя советскую политику, руководство болгарской компартии на апрельском пленуме ЦК БКП (1956 г.) объявило главной целью преодоление последствий культа личности на национальной почве. Поставленная перед обществоведами задача 
отказаться от упрощенческого и конъюнктурного подхода к историческому процессу, схематизма и субъективизма означала неизбежную ревизию трактовок и выводов «болгарского Сталина» - Червенкова о характере революции и революционного процесса в Болгарии. На страницах партийной печати развернулась в 1956-1957 гг. новая дискуссия, участники которой критиковали связанную с именем Червенкова концепцию двух этапов и «перерастания» революции [Проблеми на българската... с. 36, 37]. Основным «забойщиком» в дискуссии стал акад. Т. Павлов, опубликовавший свою статью в советском журнале «Вопросы философии» [Павлов К вопросу...], что придало его позиции дополнительный вес и установочный характер.

Как и прежде, дискуссия продемонстрировала конъюнктурный подход многих участников, в том числе и маститых, к проблеме. Равняясь на очередную партийную установку, ученые вопреки реальным фактам обосновывали «однородность» революции с самого ее начала, что выразилось в установлении пролетарской диктатуры в стране чуть ли не 9 сентября, подчеркивали незначительный масштаб общенациональных (антифашистских и демократических) задач при преобладании классовых (социалистических) и, естественно, обходили вопрос о переходном характере народной демократии.

Подгоняя под актуальные партийные формулировки конкретные реалии общественно-политической жизни после 9 сентября 1944 г., одни ученые рассуждали о «неполной» гегемонии компартии (на этой основе делался вывод о коалиционном характере системы власти), другие, напротив, указывали на «безраздельное господство» рабочего класса во главе с коммунистами в условиях «недооформленной и неукрепленной диктатуры» (отсюда отрицание факта раздела власти с буржуазией) [Чаръкчиев Характер и движещи... Попов], и т. д.

Собравшийся в июне 1958 г. VII съезд БКП подвел итоги обсуждения. В отчетном докладе ЦК, с которым выступил новый партийный лидер Тодор Живков, тезис о «превращении» или «перерастании» власти, установленной в результате восстания 9 сентября 1944 г., был подвергнут остракизму, а представления о двух этапах объявлены неправильными. Диктатура пролетариата в форме народной демократии, подчеркнул докладчик, постепенно укреплялась в условиях острой классовой борьбы, но не гражданской войны. Окончательная формулировка звучала следующим образом: «Народно-демократическая по форме революция в нашей стране с самого своего начала по своим закономерностям являлась повторением в главном Великой Октябрьской социалистической революции... продолжением дела Октябрьской революции... с самого начала она носит социалистический характер» [VII конгрес... с. 109].

Признавая болгарскую специфику - более широкая социальная база революции (среднее крестьянство, часть буржуазии), наличие самостоятельной крестьянской партии (БЗНС), функционирование национального фронта (ОФ), отказ от национализации земли, - партийные руководители и вслед за ними ученые избегали любых формулировок, могущих напомнить «ревизионистские» теории «национального социализма». Такая позиция понятна, учитывая острую реакцию Москвы на возрождение внимания к собственным путям развития в некоторых социалистических странах, а также на со- 
бытия в Венгрии и Польше в 1956 г. Задача крепить единство с Советским Союзом решалась посредством подчеркивания советского опыта, советской модели как закономерности развития «социалистического лагеря» и оттеснения на задний план своего, особенного. Подобная логика вела к оценке общедемократических и антифашистских задач как «своеобразия» болгарской социалистической революции [Даскалов, с. 318].

После VII съезда вопрос о характере революции окончательно утратил дискуссионный характер: болгарские исследователи единодушно комментировали партийную резолюцию, втискивая эмпирический материал в ее прокрустово ложе. Критическая направленность выступлений болгарских авторов была обращена отныне вовне. Т. Павлов призвал всех противников партийной установки «раз и навсегда примириться с обстоятельством, что их чрезмерно общие и негибкие формулировки не должны применяться по крайней мере по отношению к нашей, болгарской, народно-демократической по форме, социалистической по содержанию еще с 9 сентября революции. При новом издании своих трудов они должны отметить хотя бы одно - что по этому вопросу в НРБ уже есть ясно определенное и всеми признанное решение партийного съезда...» [Павлов Ощеведнъж... с. 30]. Столь откровенно высказанная от лица болгарской науки претензия установить монополию на истину сегодня предстает как анахронизм. Однако «рекомендация» Павлова явно достигла цели. Во всяком случае, советские историки вплоть до перестройки были обязаны руководствоваться установками «братской» компартии и «не обижать наших друзей!», за чем бдительно следили идеологические инстанции, прежде всего отдел науки ЦК КПСС.

Кардинальный, хотя и не единодушный пересмотр болгарскими учеными вышеозначенных партийных установок произошел в посткоммунистический период. Смена идеологической и исследовательской парадигмы, открывшийся перед историками и обществоведами широкий доступ к первоисточникам сопровождались разрывом с крайне политизированными конъюнктурными оценками «болгарского социализма» по всему широкому спектру связанных с ним понятий. Начало было положено утверждением оценки событий 9 сентября как «переворота». Это определение прочно вошло в научный обиход, но его интерпретации имели существенные различия. Одни авторы придавали перевороту характер заговорщического и едва ли не случайного события [Минчев, c. 77]. Другие, указывая на решающую роль в сентябрьских событиях внешнего фактора (выход Красной армии на болгарскую границу, соглашение союзников по антигитлеровской коалиции по Болгарии), использовали определение «переворот» в переносном смысле - как передачу Красной армией власти болгарским коммунистам. При этом значение действий болгарских партизан и всего движения Сопротивления в целом приуменьшалось [Например: Огнянов Държавно-политическата... Рачев; Стателова и др].

На волне охватившего исследователей «негативизма» [Даскалов, с. 342] новое прочтение исторического прошлого в условиях отрицания всего «коммунистического» сопровождалось появлением остро полемичных и жестких оценок «всенародного антифашистского восстания» как «полной бутафории», развенчанием «героического» захвата партизанами населенных пунктов страны, освобождения политзаключенных революционным народом и пр. [См., например: Стателова, с. 632-633.] 
Но защищали свои позиции и те исследователи, которые не приняли новых подходов.У М. Исусова читаем: «...Разгром и ликвидацию монархо-фашистской государственно-политической системы... можно было осуществить лишь (курсив мой. T.B.) путем вооруженного народного восстания, а не военного переворота». В доказательство автор приводил сведения об установлении революционной власти на местах 6-8 сентября. Главный же удар в Софии явился заслугой «капитанов», готовивших захват изнутри Военного министерства, и нескольких революционно настроенных воинских частей [Исусов Сталин и България, с. 132-133]. Версия Исусова свидетельствовала по меньшей мере о комбинированном способе захвата власти, но автор предпочел сделать итоговый вывод о «революционной волне», которая «начала заливать страну» [Там же, с. 133.] и привела к кардинальным переменам.

При наличии в целом уже сложившегося корпуса источников особое значение приобрела их интерпретация. Так, некоторые исследователи назвали совершённый военными переворот в столице «завершающим моментом начавшихся за несколько дней до него действий по захвату власти на местах и в Софии» [Калинова Възникване... с. 45]. Стремление несколько смикшировать роль военных вызвало к жизни оценку 9 сентября как «военно-политического переворота». Упор при этом делался на использовании болгарскими коммунистами военных для взятия власти в условиях вступления в страну Красной армии [Цветанова, с. 505; Вълканов, с. 85-121].

Особое внимание авторов привлекла проблема внешнего фактора, его роли в событиях 9 сентября и последующих. Под внешним фактором понималось прежде всего вступление в страну Красной армии. Здесь оценки расходились. Некоторые исследователи преуменьшали значение внешнего фактора, настаивая на главной роли фактора внутреннего (вооруженная борьба народа под руководством коммунистов) [Сирков, c. 48-49.]. Другие обращались к авторитету лидера болгарских «тесняков» Димитра Благоева, отмечавшего в свое время, что в таких странах, как Болгария, успех революции на $3 / 4$ зависит от внешних обстоятельств. Определенной корректировкой позиции Благоева стал тезис о «решающей» помощи Красной армии в сентябре 1944 г., с тем уточнением, что понятие «решающая» допускало соотношение «чуть более 1/2» [ДимитровТодор... с. 14-15]. Это означало, что внутренний фактор фактически уравновешивал фактор внешний. Отмечена в историографии также характеристика внешнего фактора как гаранта перехода к советской модели, для реализации которой впоследствии оказался достаточным фактор внутренний [Даскалов, с. 345].

Оставляя за пределами нашего внимания работы, отражающие, по удачному определению историка Р. Даскалова, «любительско-журналистские набеги на историю» [Там же, с. 483], заметим, что профессиональные болгарские историки нередко грешат эмоциональными трактовками. Подчас создается впечатление, что некоторые авторы соревнуются в хлесткости и жесткости предлагаемых формулировок. Говорится, в частности, о «духовном и физическом (!) геноциде, который ожидал все народы, оккупированные Красной армией в конце Второй мировой войны» [Цветков, с. 91], о «социалистической колонизации» обширных территорий Восточной Европы [Богданова Лошата... с. 500, 552; БогдановаПолитическа... с. 391]. Отражая в первую очередь по- 
литические воззрения противников коммунизма, сентябрь 1944 г. в Болгарии подается как «советская оккупация» и начало коммунистического тоталитаризма, приравниваемые к «перелому позвоночника» болгарской истории [См., например: Божилов, с. 499; Луджев, с. 7, 217]. Возродилось определение «национальная катастрофа»,третья по счету (после поражения Болгарии во Второй Балканской (1913 г.) и Первой мировой войнах), с которой связаны отклонение страны от «естественного исторического пути», очередное попадание в лагерь побежденных и вытеснение из «новых [территориальных] пределов» [Марков, с. 269-271].

Для большинства исследователей определение «оккупация» приобрело аксиоматический характер [Пинтев, с. 243, 248; Спасов, с. 486-487]. По мнению других, рассмотрение стран советской сферы влияния, в том числе Болгарии, как сугубо «пассивных объектов», что сопрягается с оккупационным статусом, не совсем корректно. Добиваясь большей точности, исследователи ввели в научный обиход такие понятия, как «военно-политическое влияние и контроль СССР в Болгарии», страна-«субъект с ограниченным суверенитетом» [Богданова Лошата... с. 552]. Известна и своего рода промежуточная оценка, выраженная в определении «символическая оккупация» [Зафиров, с. 96]. Отнюдь не упрощает историографическую ситуацию тот факт, что, как правило, дефиниция «оккупация» утрачивает нейтральное юридическое значение и переходит в разряд однозначных эмоционально-негативных оценок. Понятно, что читатель воспринимает их в соответствии со своим, национальным, опытом и его эмоциональной составляющей. Так, в России с термином «оккупация» связана историческая память населения о времени немецко-фашистской оккупации части территории Советского Союза. Отсюда болезненное восприятие оценок пребывания Красной армии в Болгарии как оккупации и трактовка позиции «братушек» в связи с этим едва ли не как предательство по отношению к «старшему брату».

Тяга болгарского общества к однозначной категоричности усложняет положение тех исследователей, которые предлагают рассматривать советское военное присутствие в Восточной Европе как весьма сложное, многоаспектное явление, с учетом следующих подходов:

- конкретно-юридического, призванного оценить наличие в Болгарии вплоть до декабря 1947 г. Союзной контрольной комиссии (СКК) и военных комендатур, что свидетельствует о военной оккупации страны-сателлита гитлеровской Германии;

- «общецивилизационного», предполагающего адекватную оценку исторического факта разгрома гитлеровской Германии Красной армией и силами союзников и освобождения Европы от фашизма;

- формационного, отражающего формирование в конце 1940-х годов в Восточной Европе политических левототалитарных режимов советского типа и, как «зеркальный» процесс, - восстановление «правоавторитарных монархических режимов» в условиях британского военного присутствия в Греции и Бельгии [Баев, С. 310-311].

Анализируя оккупационный статус Болгарии, исследователи задались вопросом о характере капитуляции болгарской армии - была ли она безоговорочной? Этот во- 
прос также приобрел ранг дискуссионного. Если одни авторы считали, что многие статьи Соглашения о перемирии (28 октября 1944 г.) фактически основывались на принципе безоговорочной капитуляции [Пинтев, с. 243], то другие напоминали о том, что в действительности болгарская армия не только не была разоружена и демобилизована, но сразу же перешла в оперативное подчинение командования 3-го Украинского фронта и в его составе участвовала в боевых действиях против Германии. Это обусловило возникновение особого, «промежуточного» статуса страны, который еще раньше, в британских подготовительных материалах к Московской конференции министров иностранных дел в октябре 1943 г., определялся как возможная «частичная оккупация» [Тошкова, с. 248] Показательно, что сторонники разных точек зрения сходятся в одном: по своему содержанию советско-болгарские отношения указанного периода выходили далеко за рамки формулы «победитель - побежденный», что подтверждалось, в частности, некоторыми особенностями деловых контактов болгарского правительства с СКК [Подробнее о деятельности СКК в Болгарии см.: Великите...].

Рассматривая проблему оккупации, следует разграничивать предусмотренную соглашениями участников антигитлеровской коалиции военновременную оккупацию стран-сателлитов гитлеровской Германии, в том числе и Болгарии, и политические и идеологические последствия вступления Красной армии в Восточную Европу. Тогда суждения о послевоенной советской оккупации как синониме «ограбления в чудовищных размерах» [168 часа. 14 април 2017 г.] и колонизации стран региона, в том числе и Болгарии, вряд ли можно будет рассматривать иначе как пример нового политизированного мифотворчества.

Проблема оценки событий 9 сентября по-прежнему актуальна. Основная причина кроется, по мнению болгарского историка М. Минчева, в наличии аргументов в пользу и народного антифашистского восстания, и военного переворота, и передачи власти болгарским коммунистам Красной армией. В отличие от политизированной оценки 9 сентября как социалистической революции, эти трактовки, считает автор, имеют научный характер [Минчев, с. 42-77]. Одна из наиболее авторитетных болгарских исследовательниц, проф. И. Баева, поддерживая тезис Минчева, уточняет: в стране наблюдалось множество повстанческих актов и проявлений; смена власти в столице произошла путем классического переворота; его итогом стал политический поворот в судьбе Болгарии; наконец, следствием явился прорыв в социально-экономическом развитии страны, сопоставимый с общественной революцией [Баева, с. 99]. При достаточно высоком уровне накопленных эмпирических знаний и множественности интерпретаций некоторые исследователи (в их числе и Баева) предпочитают в наши дни ограничиваться нейтральной, осторожной формулировкой «перемена 9 сентября» [Kaлинова, Баева, с. 39, 40, 44].

Крушение коммунистических режимов в странах бывшего «социалистического лагеря», последовавшее за развалом СССР, вызвало новый всплеск внимания общественности и научных кругов Болгарии к феномену народной демократии. Наряду с ее трактовками как «эксперимента», продвижения к социализму отличным от советского путем [Исусов Сталин иБългария, с. 169, 170, 220], то есть, иными словами, как альтер- 
нативы социализму «по Сталину», появились другие оценки. Например, для З. Златева «переходность» народной демократии обусловливалась существованием этой политической системы между «двумя тоталитаризмами»: опорой одного была частная собственность, а другого - огосударствленная. Вектор эволюции народной демократии, по Златеву, определился в Болгарии сравнительно быстро и четко - советская модель [Златев, с. 44-53]. Еще одна, близкая к вышеозначенной, позиция представляет народную демократию как разновидность тоталитаризма [Огнянов Политическото... с. 284, 294]. Понятно, что подобная оценка явилась производной от генеральной трактовки социализма как тоталитарной системы, обретшей в странах Восточной Европы небывалую популярность на волне критики всего советского. На этом фоне особенно привлекательно выглядят попытки вписать «болгарский социализм», как государственный социализм советского типа, в глобальный исторический процесс, оценить его через призму общих для послевоенной Восточной Европы поисков путей ускоренной модернизации региона [Баева, с.99]. Поворотная в болгарской истории дата 9 сентября 1944 г., положившая начало периоду народной демократии, вывела страну на такой путь. Результатом стал цивилизационный рывок Болгарии, который невозможно отрицать и бессмысленно игнорировать.

Различные интерпретационные схемы продолжают существовать и сегодня. Вряд ли следует ожидать, что будет найден некий «общий знаменатель». Вероятнее ситуация, которую болгарский исследователь акад. Илчо Димитров определил следующим образом: всегда есть личности и события, которые «обречены оставаться спорными и для людей, и для науки» [Димитров Между Мюнхен... с. 196-197].

\section{Литература}

Архив внешней политики Российской Федерации (далее - АВП РФ). Ф. 074.0п. 36. П. 134. Д. 8. Л. 40.

АВП РФ. Ф. 074. Оп. 45. П. 203. Д. 15. Л. 12.

АВП РФ. Ф. 074. Оп. 45. П. 203. Д. 15. Л.8-13.

Баева И. Още веднъж за Девети септември 1944 година // Понеделник. Списание за теория, политика и култура. Год. XII. 2009. № 7/8.

Валева Е.Л. Болгария в годы Второй мировой войны // Болгария в XX веке. Очерки политической истории. М. 2003.

Волокитина T.В. Программа революции. У истоков народной демократии в Болгарии. 19441946 гг. М. 1990.

Галенович Ю.М. Сталин и Мао. Два вождя. М. 2009.

Димитров Г. Избранные произведения: в 3-х томах. Т. 2. Май 1934 - август 1944 г. М. 1983.

Драбкин А. Сталин и Мао // Правда. Орган ЦК КПРФ. № 142. 17 - 20 декабря 2004 г. — URL: kprf.ru/pravda/issues/2004/142/article-6538 (дата обращения: 25.02.2019).

Информация военных корреспондентов газеты «Правда» В. Кожевникова и М. Сиволобова в ЦК ВКП(б) о положении в Болгарии // Русский архив. Т. 14-3(2) Великая Отечественная. Красная Армия в странах Центральной, Северной Европы и на Балканах. 1944-1945. Документы и материалы. М. 2000.

Милибенд Р. Парламентский социализм. Исследование политики лейбористской партии. М. 1964. 
Мрачковская И.М. Экономическая дискуссия 1951 года по проекту учебника «Политическая экономия». М. 1991.

Павлов Т. К вопросу о характере болгарской народно-демократической революции // Вопросы философии. 1956. № 6.

Российский государственный архив социально-политической истории (РГАСПИ). Ф. 575. Оп. 1. Д. 58. Л. 86.

Соболев А.И. Народная демократия как форма политической организации общества // Большевик. 1951. № 19.

Юдин П. Развитие товарищем Сталиным учения о диктатуре пролетариата // Правда. 27 июня 1949 г.

168 часа. 14 април 2017 г.

VII конгрес на Българската комунистическа партия, 2-7 юни 1958 г.: Стенографски протокол. София. 1958.

Аврамов П. Развитие на възгледа за Деветосептемврийското въстание и народнодемократичната власт (1944-1948) // Исторически преглед. 1982. Кн. 3.

Баев Й. Проблеми на българо-съветските военнополитически отношения (септември 1944 декември 1947) // България и Русия през XX век. Българо-руски научни дискусии. София. 2000.

Баева И. Още веднъж за Девети септември 1944 година.

Богданова Р. Лошата слава на най-верния сателит. Българо-съветски политически отношения след Втората световна война // България и Русия: между признателноста и прагматизма. София. 2008.

Богданова Р. Политическа иконография на «социалистическото строителство» // Известия на Българското историческо дружество. Т. 40. София. 2008.

Божилов И., Мутафчиева В., Косев К., Пантев А., Грънчаров Сm. История на България. София. 1998.

Българската комунистическа партия в резолюции и решения на конгресите, конференциите, пленумите и политбюро на ЦК.Т. 4: 1944-1955. София. 1955.

Великите сили и България. 1944-1947 г. Том 2. Съюзната контролна комисия в България (ноември 1944 - декември 1947 г.). Документи. Ч. 1, 2. София. 2018.

Вълканов В. Деветосептемврийският военнополитически преврат от 1944 година (65 години от събитието) // Исторически преглед. 2009. Кн. 3-4.

Гиндев П. За някои особености на Деветосептемврийското въстание и на нашата народнодемократическа държава в светлината на доклада на др. ВълкоЧервенков «Отечественият фронт и неговите предстоящи задачи» // Философска мисъл. 1952. № 4.

Гиндев П. Общото и специфичното в Деветосептемврийската социалистическа революция // Летопис на дружбата. София. 1975.

Горненски Н. Характер на Деветосептемврийската революция в България // България и Балканите, 681-1981. София. 1983.

Даскалов Р. От Стамболов до Живков. Големите спорове за новата българска история. София. 2009.

Димитров Г., Костов Тр., Югов А. Речи по отговора на Тронното слово пред XXVI Обикновено Народно събрание. София. 1945.

Димитров Г. Дневник. 9 март 1933 - 6 февруари 1949 г. София. 1997.

Димитров И. Между Мюнхен и Потсдам. Българската политика през Втората световна война. София. 1998. 
Димитров И. Тодор Живков за Деветосептемврийската социалистическа революция // Исторически преглед. 1985. Кн. 9-10.

Драганов Д. Съществувал ли е народнодемократичен модел на социализма? // Векове. 1989. № 4.

Зафиров Д. Проникване на съветското влияние в българското военно изкуство (1945-1960 г.) // България в сферата на съветските интереси. София. 1998.

Златев 3. Народната демокрация в България (1944-1948) // Страници от българската история. Събития. Размисли. Личности. 2. София. 1993.

История на антифашистката борба в България, 1939-1944. Т.2. Март 1943 - 9 септември 1944. София. 1976.

Исусов М. Георги Димитров и проблемите на народната демокрация // Интернационалното и националното в опита на строителството на социализма. София. 1985.

Исусов М. За някои съвременни оценки на най-новата история на България // История и обществознание. 1990. № 2.

Исусов М. Комунистическата партия и революционният процес в България. 1944-1948. София.1983.

Исусов М. Политическият живот в България. 1944-1948. София. 2000.

Исусов М. Сталин и България. София. 1991.

Калинова Е. Възникване на Отечествения фронт в годините на Втората световна война // История на Отечествения фронт в България. Том. І. София. 2012.

Калинова Е., Баева И. Българските преходи. 1939-2005 (преработено издание). София. 2006. Костов Тр. Избрани статии, доклади, речи. София. 1964.

Луджев Д. Град на две епохи. История на обществените групи в българските градове в средата на XX век. София. 2005.

Марков Г. Българската история вкратце. София. 1992.

Минчев М. За характера на Девети септември 1944 г. // Минчев М. България отново на кръстопът (1942-1946). София. 1999.

Непубликувани радиограми на Георги Димитров в ЦК на БРП(к) (август-декември 1944 г.) // Известия на Института по история на БКП. Т. 32. София. 1975.

Огнянов Л. Държавно-политическата система на България. 1944-1948. София. 1993.

Огнянов Л. Политическото развитие на България. 1944-1948 // 681-1948. Из историята на българската народност и държава. Изследвания, анализи, преоценки. София. 1993.

Павлов Т. Вълко Червенков - достоен продължител на делото на Георги Димитров и верен ученик на великия Сталин // Вълко Червенков 50 години. София. 1952.

Павлов Т. За марксическа история на България. София. 1954.

Павлов Т. Още веднъж за характера на Деветосептемврийското народно въстание: Някои теоретико-методологически въпроси на социалистическата революция. София. 1960.

Пинтев Cm. Выступление в дискуссии на «круглом столе» «Съветският фактор в развитието на България след 9 септември 1944 година» (София, април 1997 г.) // България в сферата на съветските интереси. София. 1998.

Попов П. Установяване, развитие и система на пролетарската диктатура у нас. София. 1956.

Проблеми на българската историография след Втората световна война. София. 1973.

Работническо дело. 17 декември 1949 г.

Работническо дело. 20 септември 1944 г.

Работническо дело. 27 септември 1944 г. 
Работническо дело. 29 юни 1950 г.

Рачев С. Чърчил, България и Балканите. 1939-1945. София. 1998.

Сирков Д. Антифашистката борба в България по време на Втората световна война (1939-1944). София. 1980.

Спасов Л. България и СССР. 1917-1944 (Политико-дипломатически отношения). Велико Търново. 2008.

Стателова Е., Грънчаров Ст. История на нова България. 1878-1944. София. 1999.

Съвременник. 1945. № 2.

Тошкова В. Выступление в дискуссии на «круглом столе» «Съветският фактор в развитието на България след 9 септември 1944 година» // България в сферата на съветските интереси. София. 1998.

Трети конгрес на Отечествения фронт, 28-29 май 1952 г. София. 1952.

Цветанова М. Характер на събитията на 9 септември 1944 г. // Пловдивски университет «Паисий Хилендарски». Научни трудове. История. Т. 1. Кн. 1. Пловдив. 2006.

Цветков П. Руската и съветската имперска система // България между Европа и Русия. Научна конференция. 10-11 октомври 1997 г.

Централен държавен архив на Република България (още - ЦДА). Ф. 1 Б. Оп. 12. А.e. 496. Л. 27.

ЦДА. Ф. 1 Б. Оп. 5. А.е. 42. Л. 47-48.

ЦДА. Ф. 1 Б. Оп. 5. А.е. 42. Л. 48-49.

Чаръкчиев А. Характер и движещи сили на народнодемократическата революция в България. София. 1956.

Чаръкчиев А. За характера на народнодемократическата революция в България // Въпроси за развитието на България по пътя на социализма. София. 1954.

Чаръкчиев $A$. За характера на нашата народнодемократическа революция // Философска мисъл. 1954. № 4.

Червенков В. По пътя на Георги Димитров: Избрани доклади и речи. 1948-1950. София. 1950.

Szymczak T.Ustrój europejskich państw socjalistycznych.Warszawa. 1983. 